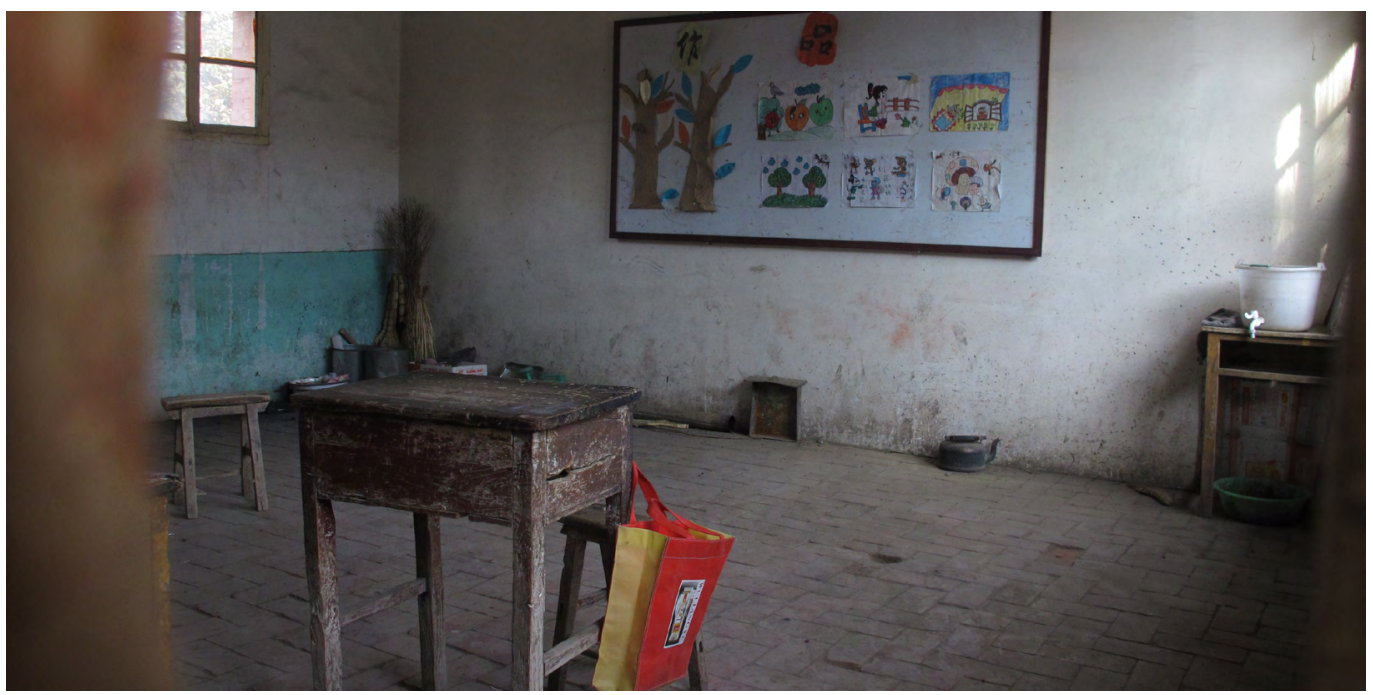

\section{Humility in the} Pursuit of Tacit Knowledge

\author{
Public-Benefit Work in \\ Poverty Alleviation and Rural \\ Development
}

ZHOU Jian

TIAN Hui

Zhou Jian kindly agreed to write for us about his experience of almost 15 years of working in poverty alleviation, rural development, and community development in different regions of China. Zhou began this work full-time following the Wenchuan earthquake in 2008. In 2012, he co-founded the Beijing Gan'en Philanthropic Foundation (北京感恩公益基金会) with prominent figures such as Wang Zhenyao (former head of the Ministry of Civil Affairs Social Welfare and Charity Division and now Dean of Beijing Normal University's China Philanthropy Research Institute), $\mathrm{Ye} \mathrm{Fu}$ (writer and poet), and Yang Lixin (actor). Although Zhou is the foundation's director, in practice, he commits much of his time to working on the 'frontlines' of
A classroom in a rural school participating in the 'One School, One Dream' (一校一梦想) project. PC: Zhou Jian. projects himself. In this essay, he shares his thoughts on the development of the 'public benefit' (公益) sector over the years as it has become increasingly focused on efficiency and competitiveness (市 场化), and on scaling up (规模化) - topics that have been hotly debated in recent years in the sector. This is combined with his reflections on working in poverty alleviation and rural development against the backdrop of two major national strategies, the 'Battle Against Poverty' (脱贫攻坚战) and 'Rural Revitalisation' (乡村振兴). Tian Hui, who is an intern at the foundation, worked with Zhou Jian to produce this essay as a form of oral history.

The Editors 
n May 2012, my partners and I co-founded the Beijing Gan'en Philanthropic Foundation. The foundation's mission is to 'foster the capacity and values of individuals to pursue a happy life'. It has, from the outset, focused on rescue relief, community development, and education. In this essay, I would like to focus on certain debates about civil society in the community development field and a few of my own thoughts on those issues based on my experience of working in this field for more than a decade since the Wenchuan earthquake.

In practice, in the Beijing Gan'en Foundation's 'public benefit' work in rural education and community-building, we have always tried to start from a place of respect for local social customs, to use people's tangible needs as a vehicle, and to integrate into the processes of a project an attempt to foster awareness of rights and responsibilities. We try to incorporate processes for public participation in, and oversight of, community affairs. With this, our aim has been to use the process itself to have an unobtrusive but positive influence on the individuals with whom we work, promoting the aims of social cohesion and mutual aid as a corollary effect.

Many people think that public-benefit work can change the world. In my view, what can really change the world is people, and change in people comes not from public-benefit work but from people themselves. What public-benefit work can do is influence people through the process of a project or an activity. The important thing is the process. When people themselves change, they can bring about a change in their own community, or in society more broadly. This is one form of value that public-benefit work can bring to society.

So, what is the value of public-benefit work? In my experience, in China's cities, people often see the point of public-benefit work as being to 'make yourself more virtuous by doing good'. In rural areas, it is a common perception that public-benefit work is mostly 'government-arranged'. In the non-profit sector, many think our role is to 'make up for the failings of public policy'. To me, this hodgepodge of ideas is not especially useful to non-profit organisations (NPOs, 公益组织) if we want to integrate ourselves into our societies, economies, and cultures to become meaningful actors in the interplay under way in China's social development.

In practice, no matter which of these views an NPO adheres to, it is likely to run into all kinds of problems with its partners, local government, and the villagers it intends to benefit. At times, these conflicts may even escalate to such an extent as to shed doubt on an NPO's professionalism and integrity.

\section{Respecting Local Capacity}

I have often observed an issue with NPO projects in rural areas that I think merits reflecting on. An NPO, for instance, might see schoolchildren in rural areas with their homemade woven bags and cotton satchels instead of rucksacks and feel a sense of 'responsibility'. They regard it as a shame for these poor kids that they do not have 'proper' rucksacks. They then go and transport huge batches of rucksacks, all one shape and style, to the countryside and hand them out to these kids. It is not uncommon to see one child being handed a dozen bags.

Conversely, someone like Eckart Löwe-a teacher from Germany who spent more than a decade teaching voluntarily in rural schools in China and to whom I spoke about his experience-would take a completely different view. He would see these children's hand-stitched bags of all different kinds as a reflection of how creative and smart, and how capable, these children are. In this small example, the NPO's act of 'kindness' unintentionally invalidates and strangles the creativity of these children, demeaning their sense of identity in the cultural context of their rural village, and undermining their sense of self-worth.

This happens not only in education. I have been to more than 150 poor counties in China, and this kind of thing is far too familiar. In my experience, many NPO projects see only materials and not people; they see only the 'pain' of others and 
not their creativity. Löwe once said that China is gutsy when it comes to a lot of things, but when it comes to education it is not. In rural education, I see all the time that NPOs focus on how 'poor' the education is in rural areas and on how they can 'improve' it. It is rare that we hear of the 'good' in this 'poor' rural education.

This kind of 'public-benefit support' comes with a sense of superiority, tying rural education neatly up into our models of 'success' through its discourse of their 'backwardness' and acting as a constant source of feelings of inferiority for these children. At the same time, it introduces new-fangled 'postmodern' approaches like 'pastoral learning' to the countryside. This facile creation of some 'special character' of rural education may appear on the surface to be all nice and nurturing but, in reality, it often ignores the real needs of these children. It gazes right past their emotional and educational needs.

Education should, in my view, be developed based on the genuine needs of those being educated. It should not be based on the subjective assumptions of those doing the educating. Similarly, the support that NPOs provide for rural education should not just come from the NPO deciding a model by itself. It should be based on the genuine needs of rural education.

In 2015, the Beijing Gan'en Foundation launched a project called 'One School, One Dream' (一校一 梦想). From the project's launch to today, it has helped small rural schools in 25 provincial-level regions of China to realise 720 'dreams' for their school communities, directly benefiting at least 82,769 children and 7,448 teachers in rural areas. The most important feature of this project is that the autonomy to decide on, or the power to agree on, the content of the project's support rests with the individual rural school itself. This enables the school to become the directing party in the project. As these individual projects set out directly from the needs of these rural schools, the schools themselves engage in the online fundraising process. Rural teachers can use their own social resources and boost their capacity to organise them. This begins a process of building a localised social support system for the school, meaning the school can shift itself from standing alone without assis- tance to becoming part of a model built together by parents, communities, and through social participation. This results in the development of a model of localised support for the sustainable development of rural education.

In public-benefit or poverty-alleviation projects, integrating efforts to foster awareness of rights and responsibilities is not just about giving the party we are supporting the autonomy to make their own decisions. We also have to consider the specific environment and economic factors, make the whole thing transparent, and put the power to oversee in the hands of the community.

\section{Not Treating People 'Merely as a Means'}

In the past few years, with the impact of the larger policy environment strategy (in the context of the national Battle Against Poverty), the community development field has gained a lot of attention. Not only NPOs, but also local governments have sought to become actively involved in poverty-alleviation and community development work. The conflicts of different ideas and understandings, and the competition that characterises this field, have become important factors influencing its development.

A county Communist Party secretary in charge of a state-designated poor county recently related a case that merits reflection. One of the strategies used in China's poverty-alleviation campaign is to relocate poor villages from areas determined to be inhospitable and unable to sustain in the long term the lives of the people living there. This case occurred in an isolated mountainous region. One of the 'designated-poor' households set to be relocated had chosen to be part of the building process (as opposed to having everything done on their behalf), but under this policy there were different ways of handling each different stage of house-building. In this case, the government had made a direct cash payment to the household for the ground-levelling stage (the part of the building project notorious for bringing the highest risk of unforeseen costs). The household was left 
to take care of the ground-levelling themselves, with the government planning to step in following completion to arrange a construction team to begin building (the part of the process for which costs are relatively stable and predictable). In the event, the household spent more on the ground-levelling process than the 10,000 yuan the government had allocated them. This household went time and again to the township government to request the additional cash to cover the costs, arguing that it was the government that had wanted to lift them from poverty in the first place; it was the government that wanted them to build this house.

This county party secretary wrote an essay criticising the designated-poor households for thinking they can milk the process by putting pressure on the cadres who they know to be under pressure, thinking, 'I'm just one of the ordinary folk, who have I got to fear?', while knowing that 'cadres have more to be anxious about', because if that household is not 'removed from poverty' the cadres cannot submit reports to their superiors on their work because they need someone from the designated-poor household to sign the poverty-alleviation form. The county secretary argued that this way of seeing things is wrong and the poor need to be educated.

To me, as someone who has worked in development for many years, the 'erroneous' views of these households are testament to Kant's view: 'Treat humanity ... always at the same time as an end, never merely as a means.' If we treat humans as a 'means' in a process (in this case, seeking to 'lift them' from poverty), it is a degradation of people's integrity. If we think about this anecdotal case, clearly the 'poor household' was aware they were being treated by the 'poverty-alleviating cadre' as a means to complete the latter's 'poverty-alleviation' duties, and so only naturally the 'poor household' in return viewed the 'poverty-alleviating cadre' as a means to realise their own needs.

In my view, the one needing 'education' in this case was the poverty-alleviation cadre and not the poor household. The cadre treated the act of 'helping' that household as the means to complete their duties rather than focusing on the people themselves as the ultimate aim. In the process of designing public-benefit projects, NPOs sometimes consider how to 'meet the needs of poor people' but do not listen carefully, observe, and respect the views of 'the poor'. Far from considering how to maintain integrity through their projects, they sometimes fail even to recognise the importance of the spontaneous knowledge of those 'poor people'the knowledge they have developed through their own everyday experiences. This being the case, it is not surprising that we often see this kind of absurd situation where cadres and 'poverty alleviators' complain that no matter what they do 'there is no satisfying people'.

Thinking back to China before 1949, I believe an important reason the Chinese Communist Party (CCP) was able to defeat the Kuomintang and take power on the mainland was that the Kuomintang's attempts to transform Chinese society relied on a kind of 'elite-designed' model. The CCP attempted to use a model that combined elite thinking with some level of respect for the spontaneous ways and needs of rural people at that time. From the perspective of treating people 'as an end, never merely as a means', that practice-now referred to as Mao Zedong Thought, which combines 'Marxism-Leninism' with 'Chinese revolutionary practice'-attempted to satisfy the natural desires of China's peasantry by 'beating tyrant landowners and distributing the land', using 'the communist ideal' to satiate human integrity.

None of this is to say that the efforts of NPOs and poverty-alleviation cadres are entirely without merit. The point is that we should not treat human nature as a means of achieving some given end. When NPOs are designing 'rational public-benefit actions' as a means to satisfy the natural desires of 'poor people', we need to think about using means that do not jeopardise people's integrity for the sake of accomplishing some poverty-alleviation or public-benefit task.

\section{Pursuing Tacit Knowledge}

At the Beijing Gan'en Foundation, we developed a project, based on this kind of understanding, called 'Lighting the Countryside, Brightening Homes' (点 
亮乡村光明万家). Part of the project is to meet the tangible needs of villagers by helping rural areas to install solar-powered streetlights. But the aim of the project is achieved by including villagers in deciding where to position the lights, in small donations, and in arranging for 'designated-poor' households to be employed throughout the project.

Even with this design, which attempts to involve local knowledge throughout the process, during implementation, we still found our foundation's project team lacked sufficient understanding of the locals' spontaneous knowledge. This led to problems in practice when what we thought of as 'rational' came into conflict with the reality there.

For example, in this Lighting the Countryside project, our partners employ people from local designated-poor households, according to the foundation's requirements, to participate in the installation work. Based on management experience from working in a 'modern' urban environment, the project operators asked that our partners require all employees to first complete a form giving a family member as their emergency contact. We thought of this as a run-of-the-mill request but found in practice that the construction partners and the people they were employing all refused.

In the view of our implementing partners, in case of an accident involving these employees, the first point of contact should be the village party branch, the villagers' committee, and the township government, and not the family members of the 'poor person' they had employed. The partners explained their concern to our project team: if anything were to happen and there were no cadres from the party branch, the villagers' committee, or the township government present, they could not be sure of how the situation would play out.

I have been working in rural areas on these kinds of projects for many years now (for more than four months of every year) and I think I have developed a fair understanding in the places I have worked of the local political, social, and cultural structures and the ways conflicts and problems are sometimes resolved. But as soon as we heard this from our partners, we recognised that our foundation's method on this issue was overly bureaucratised. The construction partners were focusing on how to act as quickly as possible to save lives, how to find the fastest way to solve the problem, and their thinking was clearly more effective than our own. In this case, we adopted the method proposed by this partner and changed our protocol for dealing with accidents in the implementation process.

In reflecting on this small example, we realise that in the process of implementing projects in rural areas where the NPO comes in from outside, there are often tacit and spontaneous types of knowledge that may be un-articulatable but that are vital to a project's success. This demands that we have the capacity to be close to the ground and learn from the places where we are working. It is something that unfortunately gets lost or overlooked in a lot of the top-down work of NPOs and poverty-alleviation cadres.

The philosopher Michael Polanyi in his 1958 book Personal Knowledge: Towards a Post-Critical Philosophy, discussed an important component of human knowledge that he called tacit knowledge. Human knowledge can partly be clearly expressed but there is another component that cannot be articulated, that cannot be separated from the behaviour of an individual, and that can only be sensed. This kind of cognition-knowledge that is sensed-is the basis, the essence, of all knowledge.

The sense-based knowledge about which Polanyi wrote, be it for NPOs or for individuals, can bring about a complete transformation in knowledge and create entirely new knowledge structures. Taking the above example, on the question of 'who to contact in case of an emergency', the problem locals raised with our original method brought precisely this kind of shift in our understanding as a foundation.

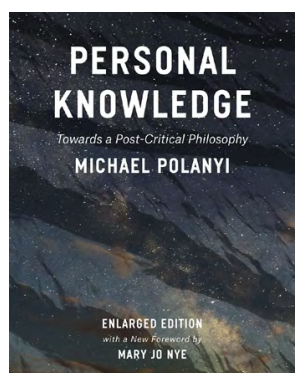

Personal Knowledge: Towards a Post-Critical Philosophy, Michael Polanyi, 1958.. 
In my view, today's NPOs often tend to rely too much on the 'modern rational knowledge' of their urban origins, designing projects based on an overly simple, general judgement of the economies or moralities found in rural areas instead of adopting a multidimensional perspective and method to develop their projects. For example, there is currently a lot of discussion among China's NPOs on how to carry out work under the national strategy of 'revitalising the countryside' (乡村振 兴). But these discussions tend to focus on 'professionalism', how to 'scale up', and how to 'replicate' projects. In reality, in 'rural revitalisation' projects, 'professionalism' is just a part of it, using the right methods to help rural areas and the people who live there.

A more important part of the discussion, in my view, should be how to make sure we on the 'frontlines' of these projects are listening more to this tacit knowledge, how to maintain humility and openness when it comes to knowing. This, for me, is the only way that we as NPOs can embed a kind of 'modern public benefit' (现代公益) in China's rural social, political, and economic practices.

We talk a lot about how to 'develop' people in the process of a public-benefit project, but what we speak less of is how to set out from a perspective of true respect for people, from a place where we are able to understand and foster their 'strengths', where we can learn from their tacit knowledge. This is something that I think is deserving of much more attention from us all.

Translated by Holly SNAPE 
This text is taken from Made in China Journal: Volume 6, Issue 1, 2021, edited by Ivan Franceschini and Nicholas Loubere, published 2021 by ANU Press, The Australian National University, Canberra, Australia.

$$
\text { doi.org/10.22459/MIC.06.01.2021.09 }
$$

